\title{
ラマン分光を用いた垂直配向単層カーボンナノチューブ膜の熱伝導特性計測*
}

\author{
石川 桂 ${ }^{* 1}$ ，千足 昇平 ${ }^{* 1}$ ， バダル サイフッラー ${ }^{* 2}$ \\ トゥラキットセーリー ティーラポン ${ }^{* 2}$, 堀 玩磨 ${ }^{2}$ \\ 項 榮 ${ }^{* 3}$, 渡辺 誠 ${ }^{* 1}$, 塩見淳一郎 ${ }^{* 1}$, 丸山茂夫 ${ }^{* 4}$
}

\section{Heat Conduction Characteristics of Vertically Aligned Single-Walled Carbon Nanotubes Measured by Raman Spectroscopy}

\author{
Kei ISHIKAWA, Shohei CHIASHI, Saifullah BADAR, Theerapol THURAKITSEREE, \\ Takuma HORI, Rong XIANG, Makoto WATANABE, Junichiro SHIOMI \\ and Shigeo MARUYAMA ${ }^{* 4}$ \\ ${ }^{*}$ The Univ. of Tokyo, Dept. of Mechanical Engineering \\ 7-3-1 Hongo, Bunkyo-ku, Tokyo, 113-8656 Japan
}

In this work, the film thermal conductivity and the film-substrate interfacial thermal contact resistance of vertically-aligned single-walled carbon nanotube (VA-SWNT) films were measured with a proposed method utilizing temperature dependence of Raman spectrum. The proposed method harnesses the excitation laser power of the Raman spectroscopy to heat the VA-SWNT films synthesized on a silicon substrate by alcohol catalytic chemical vapor decomposition (ACCVD) method, and measures film temperature from the Raman spectrum. A relationship between the input laser heat and the measured temperature is modeled with a detailed heat conduction equation, and its numerical solutions were compared with the experimentally measured results to extract the film thermal conductivity and the film-substrate interfacial thermal contact resistance. The method found the thermal conductivity of the VA-SWNT film to be around $2 \mathrm{Wm}^{-1} \mathrm{~K}^{-1}$ and the film-substrate interfacial thermal contact resistance to be around $2 \times 10^{-6}$ $\mathrm{m}^{2} \mathrm{KW}^{-1}$. The obtained film thermal conductivity corresponds to the thermal conductivity equivalent of an individual SWNT of several tens of $\mathrm{Wm}^{-1} \mathrm{~K}^{-1}$. This value was more than an order of magnitude smaller than the values reported on individual SWNTs.

Key Words : Carbon Material, Thermal Property, Thermal Contact Resistance, Spectroscopic Measurement

\section{1. 緒言}

カーボンナノチューブは高い熱伝導率を持つことが期待されており，孤立したカーボンナノチューブからなる 理想的な系での理論モデルに基づく数值シミュレーション(1)(11)や, 架橋構造をしたナノチューブの測定 ${ }^{(12)-(23)} に$

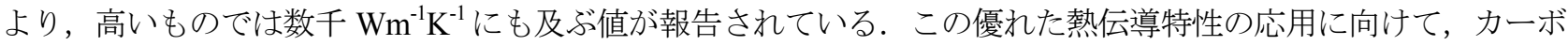
ンナノチューブを膜厚方向に配向した垂直配向カーボンナノチューブ(vertically aligned carbon nanotube, VACNT) 膜が新たな熱界面材料(thermal interface material, TIM)の候補として検討されている. VACNT を用いた TIM は，カ 一ボンナノチューブが持つ高熱伝導率に加えて，優れた機械的順応性に由来する低い接触熱抵抗が期待されるこ

\footnotetext{
* 原稿受付 2012 年 9 月 3 日

*11 正員, 東京大学（干113-8656 東京都文京区本郷 7-3-1）

*2 東京大学 (

*3 中山大学（干510275 広東省広州市海珠区新港西路 135 号）

$*_{4}$ 正員, フェロー，東京大学（干113-8656 東京都文京区本郷 7-3-1）

E-mail: maruyama@photon.t.u-tokyo.ac.jp
} 
とから，既存の TIM と比較して低い熱抵抗の実現が期待される. また，カーボンナノチューブが物理的・化学的 に不活性であるため，VACNT は長期的な安定性と温度耐性においても優れている．長期的な安定性は，一般的 な TIM が混合物であり時間とともに拡散を起こすのに対し, カーボンナノチューブは単体の物質であることに由 来する．また温度而性は，一般的な TIM の使用温度が 120 200 ${ }^{\circ} \mathrm{C}$ に制限されているのに対し，ナノチューブは 400 $600{ }^{\circ} \mathrm{C}$ といら高温にならないと空気と反応しないことに由来寸る(24). これらの優位点から VACNT は現状の TIM よりも幅広い応用が期待され次世代の TIM として有望であり, より高い熱出力密度をもつ次世代の高出力密 度エレクトロニクスに対応するTIM としても有望である.

VACNT の熱物性については, 多層カーボンナノチューブ(multi-walled carbon nanotubes, MWNTs)について数多 くの研究が行われている一方 ${ }^{(25)(35)}$, 近年垂直配向単層カーボンナノチューブ(vertically-aligned single-walled carbon nanotubes, VA-SWNTs)膜に関する研究が進んでいる。そのうち，スーパーグロース法(36)を用いて合成した VA-SWNT 膜の熱伝導率は $1.9 \mathrm{Wm}^{-1} \mathrm{~K}^{-1}$ と報告されている(37). また, プラズマCVD法 ${ }^{(38)}$ を用いて合成したVA-SWNT 膜に $\mathrm{Al}$ 及び Pd を堆積させ, SWNT 一本当たりの熱伝導率を $3000 \mathrm{Wm}^{-1} \mathrm{~K}^{-1}$ と仮定した場合の膜の熱抵抗は $1.2 \times 10^{-5}$ $\mathrm{m}^{2} \mathrm{KW}^{-1}$ である(39). さらに，アルコール触媒 CVD(ACCVD)法 ${ }^{(40)}$ とって合成した VA-SWNT 膜に各種金属( $\mathrm{Al}$, Ti, $\mathrm{Pd}, \mathrm{Pt}, \mathrm{Ni})$ を蒸着し，金属一膜間の接触熱抵抗を $3.8 \sim 9.2 \times 10^{-6} \mathrm{~m}^{2} \mathrm{KW}^{-1}$ ，膜一基板間の接触熱抵抗と膜の熱抵抗を足 し合わせたものは3.3 4.6×10 $0^{-5} \mathrm{~m}^{2} \mathrm{KW}^{-1}$ と測定されている ${ }^{(41)}$.

これらの測定によりVA-SWNT 膜の伝熱特性についての諸側面が明らかになったが，これらの測定データには サンプルの違いに由来すると考えられる一桁もの熱伝導率のばらつきがあり，また各種仮定を用いているために はっきりと得られていない物性がある，まずサンプルの違いであるが，合成方法に由来するサンプルの品質から の影響と，使用した基板が異なることという二つの要因があり，これらは測定データのばらつきにつながった可 能性がある. また, 導出にあたって各種仮定を用いるものもある. これらより, 熱伝導率が期待されるような高 さを持つかという点及び, 膜一基板間の接触熱抵抗については不明な部分が多い.

そこで本研究では, ACCVD 法を用いて合成された VA-SWNT 膜について, ラマン分光の励起レーザー光によ る加熱効果を用いて熱伝導率及び膜一基板間の接触熱抵抗を測定する方法を提案し, 測定された熱伝導特性につ いて考察する.

\section{2. 実験方法}

本研究においては, ラマン分光に用いる励起レーザー光によるサンプルの加熱と, SWNT から生じるラマン散 乱スペクトルに見られる $\mathrm{G}$ バンドピークの温度依存性（Appendix A 参照）を用いて熱伝導特性の測定を行う。ま ず，ラマン分光に用いる励起レーザー光により VA-SWNT 膜サンプルを加熱する. この励起レーザー光は膜の上 端近傍にて吸収され，生じるラマン散乱も上端近傍に由来するため, 測定されるラマン散乱スペクトルから上端 近傍の温度を得ることができる(図 1). この温度と励起レーザー光による流入熱量の関係を, 熱伝導方程式の解と 比較することにより熱伝導特性を求める.

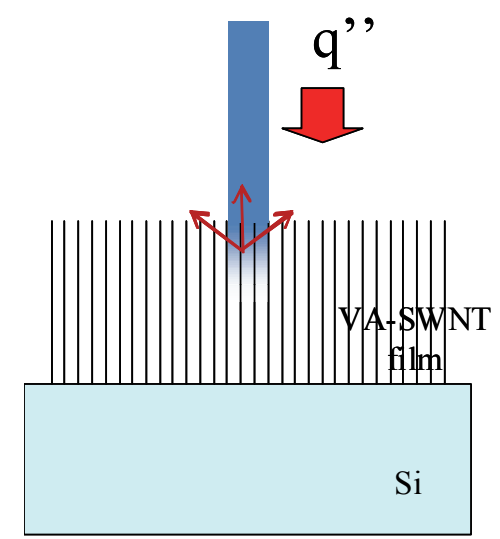

Fig. 1 Schematics of the measurement. The incident laser irradiates the VA-SWNT film, and the heated spot produces Raman scattering containing temperature information. 
各種影響（励起レーザー光のガウス分布・励起レーザー光の膜内での強度分布・横方向の熱伝導）を考慮した 熱伝導方程式を用いて, 測定結果より膜の熱伝導率と膜一基板間の接触熱抵抗を求める方法の概要を以下に示す. まず，解析的に求められる横方向熱伝導を無視した 1 次元熱伝導方程式の解と，ラマン散乱スペクトル信号強度 の温度依存性などをもとに，各膜厚においてラマン散乱信号を発している代表座標を決定する．次に，膜厚の異 なる複数のサンプルについてラマン散乱光を測定し, 励起レーザー光による投入熱量およびラマン散乱スペクト ルにより得られる温度を求める. 一方で, 縦方向熱伝導率・膜一基板間接触熱抵抗をパラメータとして上述の各 種影響を考慮した三次元熱伝導方程式を数值的に解き, 先の代表座標での温度を計算する. これらを, 膜厚一温 度グラフ上において各膜厚での測定值と比較し, 差が最小になる縦方向熱伝導率と膜一基板間接触熱抵抗の組み 合わせを求める。

\section{$2 \cdot 1$ 各種影響を考慮した三次元円筒座標系の熱伝導方程式の導出}

ここでは各種影響（励起レーザー光のガウス分布・励起レーザー光の膜内での強度分布・横方向の熱伝導）を 考慮した熱伝導方程式を導出する. まず励起レーザー光の膜内での吸収を考慮して熱伝導方程式を導出し, 続い て膜一基板間の接触熱抵抗から境界条件を求める.

本系では円筒座標系を用いる. 励起レーザー光の強度がガウス分布に従うと仮定し, 円筒座標系における位置 $r$ でのレーザーパワーを $I(r)$ とすると，

$$
I(r)=I_{0} e^{-\frac{2 r^{2}}{r_{0}^{2}}}
$$

と表せる.ここで $2 r_{0}$ は励起レーザー光のスポット径， $I_{0}$ は定数である. 励起レーザー光の出力パワーを $P$ とす ると，

$$
P=\int_{0}^{\infty} I(r) \cdot 2 \pi r d r=\int_{0}^{\infty} I_{0} e^{-\frac{2 r^{2}}{r_{0}^{2}}} \cdot 2 \pi r d r=\frac{I_{0} \pi r_{0}^{2}}{2}
$$

となり, 位置 $r$ でのレーザー強度は以下の式で表現できる.

$$
I(r)=\frac{2}{\pi r_{0}^{2}} P e^{-\frac{2 r^{2}}{r_{0}^{2}}}
$$

次に膜内でのレーザー強度を求める. 励起レーザー光は Lambert-Beer 則に従って膜に吸収されるため, VA-SWNT 膜中の座標 $(r, z)$ におけるレーザー強度 $I(r, z)$ は,

$$
I(r, z)=\frac{2}{\pi r_{0}^{2}} P e^{-\frac{2 r^{2}}{r_{0}^{2}}} e^{-\alpha z}
$$

である.ここで，膜の上端を $z=0$, 吸光係数を $\alpha$ とした．なお，VA-SWNT 膜の反射率が約 $10^{-2}$ であることから レーザー光の基板での反射による影響を無視した ${ }^{(42)}$.ここで単位体積当たりのVA-SWNT 膜の加熱量を $w$ ”” $(z)$ と すると，

$$
w^{\prime \prime \prime}(z)=-\frac{\partial I}{\partial z}
$$

であるから，

$$
w^{\prime \prime \prime}(z)=\alpha \frac{2}{\pi r_{0}^{2}} I_{\text {total }} e^{-\frac{2 r^{2}}{r_{0}^{2}}} e^{-\alpha z}
$$


となる．この項を内部発熱項として代入した熱伝導方程式は

$$
k_{r}\left(\frac{\partial^{2} T}{\partial r^{2}}+\frac{1}{r} \frac{\partial T}{\partial r}\right)+k_{z} \frac{\partial^{2} T}{\partial z^{2}}+\alpha \frac{2}{\pi r_{0}^{2}} I_{\text {total }} e^{-\frac{2 r^{2}}{r_{0}^{2}}} e^{-\alpha z}=0
$$

である．ここで $k_{r}$ は膜の横方向熱伝導率， $k_{z}$ は膜の縦方向熱伝導率とした．この熱伝導方程式は，励起レーザー 光のガウス分布・励起レーザー光の膜内での強度分布・横方向の熱伝導を考慮したものである.

続いて膜一基板間の接触熱抵抗から境界条件を求める. 膜一基板間の接触熱抵抗を第三種境界条件として取り 入れ，それ以外の境界を断熱条件とすると，

$$
\left.\frac{\partial T}{\partial r}\right|_{r=0}=0,\left.\frac{\partial T}{\partial r}\right|_{r=r_{\text {rounday }}}=0,\left.\frac{\partial T}{\partial z}\right|_{z=0}=0,-\left.k_{z} \frac{\partial T}{\partial z}\right|_{z=L}=\frac{1}{R_{\text {contact }}}\left(T(r, L)-T_{\text {sub }}\right)
$$

と表せる.ここで $R_{\text {contact }}$ は膜一基板間の接触熱抵抗， $T_{\text {sub }}$ は基板温度， $L$ は膜厚， $r_{\text {boundary }}$ は温度変化の生じる領域 と比べて十分に大きい值とした.

\section{$2 \cdot 2$ 一次元熱伝導モデルの導出}

前節で導出した三次元熱伝導方程式から数值的に求まる温度を，測定されるラマン散乱スペクトルから求まる 温度と比較寸る際に用いる代表位置の特定には，解析解が容易に求められる一次元熱伝導モデルを用いる.

三次元モデルで考慮した各種影響（励起レーザー光のガウス分布・励起レーザー光の膜内での強度分布・横方 向の熱伝導）のうち，本モデルでは励起レーザー光の膜内での強度分布のみを考慮する．まず励起レーザー光の ガウス分布についてはスポット内にて強度一定とモデル化する．次に膜内の励起レーザー光強度分布は，三次元 モデルと同様 Lambert-Beer 則に従い吸収されるとする．また，横方向の熱伝導は無視する．以上より図 2a のよ うな柱状のモデルとなる.

この一次元モデル式を以下に示す. 吸光係数を $\alpha$, 励起レーザー光の出力パワーを $P$, 膜表面を $z=0$ とすると, 膜内の位置 $z$ において入射レーザーの強度は $I_{I D}(z)=P \mathrm{e}^{-a z}$ である. 単位長さあたりの VA-SWNT 膜の加熱量を $Q^{\prime}(z)$ とすると，

$$
Q^{\prime}(z)=-\frac{d I_{1 D}}{d z}=\alpha P e^{-\alpha z}
$$

である．励起レーザー光による VA-SWNT 膜の加熱量の合計は,

$$
\int_{0}^{L} Q^{\prime}(z) d z=P\left(1-e^{-\alpha L}\right)
$$

である. スポット面積を $A$ とすると合計の熱流束は $P\left(1-e^{-\alpha L}\right) / A$ であり, 合計熱流束とは $z=L$ における熱流束で あるので

$$
-\left.\lambda \frac{\partial T_{1 D}}{\partial z}\right|_{z=L}=P\left(1-e^{-\alpha L}\right) / A
$$

となる．ここで $T_{I D}(z)$ は一次元モデルでの温度分布である.

ところで，単位体積あたりの加熱量を $w$ ”とすると図 $2 \mathrm{~b}$ に示す内部発熱のある一次元系の熱伝導方程式は

$$
\frac{\partial}{\partial z}\left(k_{z} \frac{\partial T_{1 D}}{\partial z}\right) A \Delta z+w^{\prime \prime \prime} A \Delta z=0
$$

である. ここで， $Q^{\prime}(z)=w^{\prime \prime} A$ であるので， 


$$
\frac{\partial}{\partial z}\left(k_{z} \frac{\partial T_{1 D}}{\partial z}\right) A+Q^{\prime}(z)=0
$$

となり，これはすなおち

$$
\frac{\partial^{2} T_{1 D}}{\partial z^{2}}+\frac{\alpha P}{k_{z} A} e^{-\alpha z}=0
$$

である。

次に，境界条件を設定する.VA-SWNT 膜の上側の表面 $(z=0)$ で断熱と仮定し，第一の境界条件として，膜表面 $z=0$ にて熱流束が 0 , すなわち

$$
\left.\frac{\partial T_{1 D}}{\partial z}\right|_{z=0}=0
$$

を適用する. 一方，膜一基板界面にて接触熱抵抗 $R_{\text {contact }}$ があることから，第二の境界条件が定まり， $z=L に て ，$

$$
-\left.k_{z} \frac{\partial T_{1 D}}{\partial z}\right|_{z=L}=q^{\prime \prime}=\frac{1}{R_{\text {contact }}} \Delta T=\frac{1}{R_{\text {contact }}}\left(T_{1 D}(L)-T_{\text {sub }}\right)
$$

である．これは式変形すると，

$$
T_{1 D}(L)=T_{\text {sub }}+\Delta T=T_{\text {sub }}+q^{\prime \prime} R_{\text {contact }}=T_{\text {sub }}+\frac{P}{A}\left(1-e^{-\alpha L}\right) R_{\text {contact }}
$$

となる．これらの境界条件を用いて熱伝導方程式を解くと，解析解は次のように表現される.

$$
T_{1 D}(z)=\frac{P}{k_{z} A}\left(\frac{1}{-\alpha} e^{-\alpha z}-\frac{1}{-\alpha} e^{-\alpha L}-(z-L)\right)+\frac{P}{A}\left(1-e^{-\alpha L}\right) R_{\text {contact }}+T_{\text {sub }}
$$

\section{$2 \cdot 3$ 一次元モデルを用いた代表座標の決定}

本研究では，三次元熱伝導モデルの温度解のある代表位置の温度を，計測されるラマン散乱スペクトルから求 められる温度とする. 横方向の代表位置は励起光の分布の標準偏差から定め, 縦方向の代表位置は先の一次元モ デルより得られる温度から膜厚ごとに算出する。まず横方向の代表位置については，三次元モデルにおいて励起 レーザー光がガウス分布 $\exp \left(-2 r^{2} / r_{0}{ }^{2}\right)$ を示すと仮定し，その標準偏差 $\sigma=r_{0} / 2$ を信号が測定される位置とする. 次に縦方向の代表位置については，励起レーザー光が膜中で減衰する効果・発生したラマン散乱光が膜中で減衰 する効果・ラマン信号の温度依存性の三つを考慮して算出する. まず，励起レーザー光が Lambert-Beer 則により 減衰される効果は $f(z)=e^{-\alpha z}$ である. 次に, 発生したラマン散乱光が Lambert-Beer 則により減衰される効果は $g(z)=e^{-\alpha z}$ である. そして $T(z)$ を $z$ における温度とすると, ラマン散乱の信号強度の温度依存性は $h(z)=e^{-T(z) / 491}$ で ある(44). 従って, これらをかけあわせた $f(z) g(z) h(z)$ に比例した強度のラマン散乱がそれぞれの位置 $z$ から生じ,

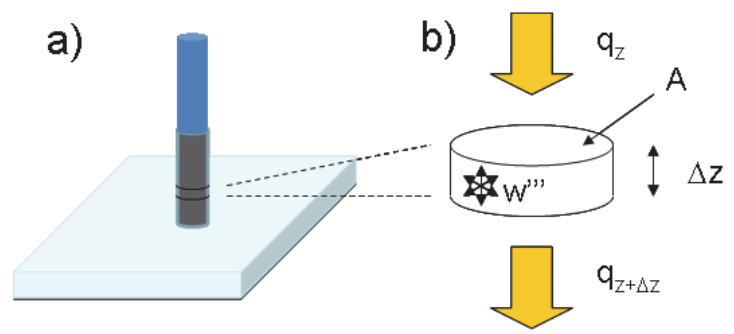

Fig. 2 a) Schematic illustration of the essence of the one-dimensional model. The gray column denotes the laser irradiated part of the VA-SWNT film. b) Derivation of the partial differential equation from the columnar fragment. The columnar fragment has heat input $q_{z}$, heat output $q_{z+\Delta_{z}}$, and heat production $w$ "'. These incoming and outgoing heat gives the partial differential equation. 
それを足しあわせたものが計測される，そこで，膜厚 $L$ における代表位置 $p(L)$ を

$$
p(L)=\frac{1}{f(0) g(0) h(0)} \int_{0}^{L} f(z) g(z) h(z) d z
$$

とする．ただしこの代表座標の定義には，顕微鏡の焦点位置からずれている部分について信号が弱くなる効果は 含まれていない，以上のように縦横の代表座標を決定し，その代表座標での三次元温度解を分光器にて測定され る温度とする。

\section{3. 測 定}

\section{$3 \cdot 1$ サンプル合成と実験装置}

ディップコート法によって Si 基板上に触媒金属として Co および Mo を担持し, ACCVD 法(41) を用いて VA-SWNT 膜を合成した，その際，合成時間を調整することで膜厚の異なる VA-SWNT 膜サンプルをいくつか合 成した.

用いたラマン分光装置はセキテクノトロン(株) 顕微ラマン装置 STR 250 をもとにしたものであり, 波長 $488 \mathrm{~nm}$ の Arイオンレーザーを励起レーザー光源とした. 対物レンズはオリンパス(株) LUCPLFLN 40x を用いた. また, 測定への対流の影響やサンプルの空気との反応を低減するために, 測定は低圧環境（20 30 Torr）にて行った.

\section{$3 \cdot 2$ 測定}

SEM 観察により膜厚を測定しておいた VA-SWNT 膜について, 励起レーザー光を高出力にしたラマン分光にて 測定を行う．ラマン分光測定では，励起レーザー光をそのまま照射した場合（高出力）と N/D フィルターにより 1/10 に減衰させて照射した場合（低出力）の二通りの計測を交互に行い，それぞれにて得られたラマン散乱のピ ーク波数の差分をとる. 二通りの計測のうち, 高出力計測はサンプル温度変化とピークシフトを測定するためで あり，低出力計測はリファレンスとしての常温でのピーク波数を求めるためである.この二通りの測定を交互に 行い時定数が数時間になる励起レーザー光の波長の温度ドリフトを相殺する. なお，この測定に用いる高出力計 測のレーザーパワーは, ピーク波数変化を明確に測定できる程度の強度でありながら SWNT 膜の性質を変化させ ない程度に弱くなければならない，これらを考慮し本研究では励起レーザー光出力を $0.7 \mathrm{~mW}$ とした，なお，低 出力計測での励起レーザー光による温度上昇は, 高出力計測での温度上昇のおよそ $10 \%$ あり 小さいため, ない とした.

ここで, 入射レーザー光による $\mathrm{Si}$ 基板の加熱効果は無視できる. 本研究の系を，Yovanovich ら ${ }^{(43)}$ にる「等方 性半空間での円熱源」における「複合及び等方円盤状の円形熱源についての広がり抵抗」としてモデル化すると, $\mathrm{Si}$ 基板での広がり抵抗が求まり，そこから基板の温度上昇が導出できる.ここで一般に広がり抵抗とは，熱源の 温度とヒートシンクの温度を熱源からの熱量で除したものであり, 本研究では Si 基板をヒートシンクとみなした. これに $\mathrm{Si}$ の熱伝導率 $149 \mathrm{Wm}^{-1} \mathrm{~K}^{-1}{ }^{(44)}$ 及びスポット径 $4 \mu \mathrm{m}$ を代入すると, $\mathrm{Si}$ 基板での広がり抵抗は $880 \mathrm{KW}^{-1}$ とな る. さらに入射レーザー光強度を代入すると, 基板での温度上昇は $0.6 \mathrm{~K}$ である. これは VA-SWNT 膜にて生じ ると見込まれる 200 300 K の温度上昇と比較すると十分小さい. よって入射レーザー光による基板の温度上昇は

Table 1 Representative position estimated from the one-dimensional model. This representative position is used for approximating the numerical temperature solution of the three-dimensional equation.

\begin{tabular}{|r|r|}
\hline $\begin{array}{c}\text { Thickness } \\
(\mu \mathrm{m})\end{array}$ & $\begin{array}{c}\text { Position } \\
(\mu \mathrm{m})\end{array}$ \\
\hline 3.9 & 2.39 \\
\hline 8.0 & 3.33 \\
\hline 11.5 & 3.68 \\
\hline 14.6 & 3.85 \\
\hline 17.0 & 3.93 \\
\hline
\end{tabular}



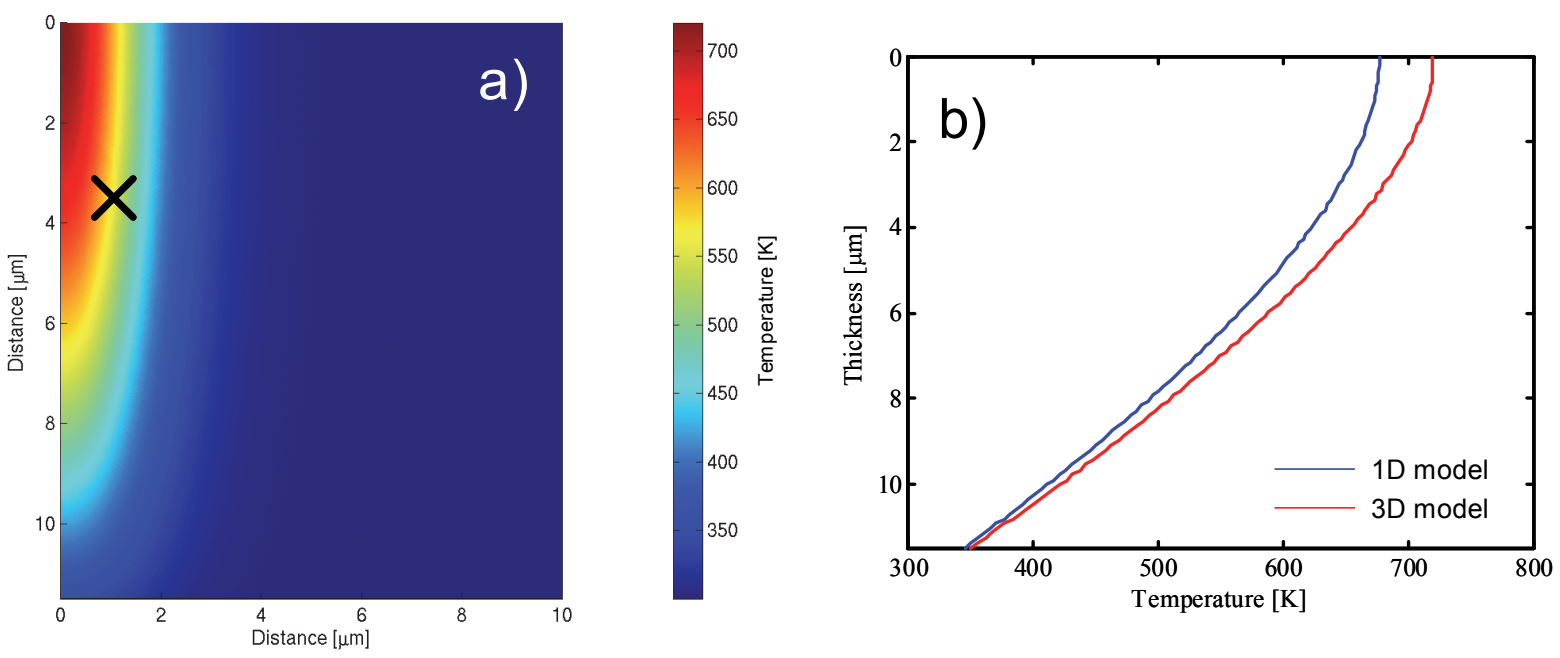

Fig. 3 Simulated temperature distribution inside $11.5 \mu \mathrm{m}$ thick VA-SWNT film. a) 3D model b) comparison of the results of 3D model at $z=0$ and 1D model. The red line indicates the solution of the three-dimensional cylindrical coordinate heat transfer equation. The blue line denotes the solution of the one-dimensional model.

The following assumptions were made on both figures, the vertical thermal conductivity of the film $k_{z}$ to be $1 \mathrm{Wm}^{-1} \mathrm{~K}^{-1}$, the lateral thermal conductivity $k_{r}$ to be $0.01 \mathrm{Wm}^{-1} \mathrm{~K}^{-1}$ (for $3 \mathrm{D}$ model result), and the film-substrate interfacial thermal contact resistance $R_{\text {contact }}$ to be $1 \times 10^{-6} \mathrm{~m}^{2} \mathrm{KW}^{-1}$.

無視した.

\section{$3 \cdot 3$ 代表座標の決定 · 三次元モデルの数値計算 · 一次元モデルの妥当性評価}

$2 \cdot 3$ 節で導出した式に実際の值を代入し代表座標を算出する. 横方向の代表位置については, 入力レーザー光 のスポット径を $2 r_{0}=4 \mu \mathrm{m}$ とすると $r=\sigma=r_{0} / 2=1 \mu \mathrm{m}$ である. 縦方向の代表位置については, 縦方向熱伝導率を $k_{z}=1 \mathrm{Wm}^{-1} \mathrm{~K}^{-1}$, 膜一基板間接触熱抵抗を $R_{\text {contact }}=1 \times 10^{-6} \mathrm{~m}^{2} \mathrm{KW}^{-1}$ としたときのそれぞれの膜厚 $L$ における代表位置 $p(L)$ を計算した結果を表 1 に示寸。これらを用い，数值シミュレーション結果の代表座標 $(r, z)=(\sigma, p(L))$ における 温度を代表温度とする.

三次元円筒座標系の熱伝導方程式および境界条件をもとにComsol Multiphysics を用いて数值シミュレーション を行う. 実験条件は, 入カレーザー光パワー $P$ を $0.7 \mathrm{~mW}$ とし, 基準温度を $300 \mathrm{~K}$ とした. また吸光度 $\alpha$ は $0.147 \times 10^{6}$ $\mathrm{m}^{-1}$ であり ${ }^{(45)}$, 計算領域の半径方向の境界位置をその位置での温度変化がほとんどない $r_{\text {boundary }}=10 \mu \mathrm{m}$ とし, 入力 レーザー光のスポット径 $2 r_{0}$ を $4 \mu \mathrm{m}$ とした. 熱伝導率の縦横比は分子動力学シミュレーションにより得られたバ ンドルの縦横熱伝導率比から決定した. 分子動力学シミュレーションにより求められた SWNT 1 本とそれを囲む SWNT 6 本との間の界面熱コンダクタンスは約 $10 \mathrm{MWm}^{-2} \mathrm{~K}^{-1}$ であり ${ }^{(9)}$ ，これを用いて縦横比を計算すると 100:1 程度になる.VA-SWNT 膜を SWNT が密集して詰め込まれた系と近似し, SWNT1 本とそれを囲む6 本との間の 縦横熱伝導率比を用い, VA-SWNT 膜の熱伝導率の縦横比は 100:1 とした. 第 4 章にてこの比率を変化させてそ の影響を検証する. なおこの值は, Wiedemann-Franz 則は用いることのできない系ではあるが，VA-SWNT 膜の電 気伝導率 100:1 程度(46) と同じような比になっている. 以上より縦方向の熱伝導率を $1 \mathrm{Wm}^{-1} \mathrm{~K}^{-1}$, 横方向を 0.01 $\mathrm{Wm}^{-1} \mathrm{~K}^{-1}, \mathrm{Si}$ 基板と VA-SWNT 膜の間の接触熱抵抗 $R_{\text {contact }}$ を $1 \times 10^{-6} \mathrm{~m}^{2} \mathrm{KW}^{-1}$ と仮定して得られた VA-SWNT 膜断面 の温度分布を図 3a に示す.

一次元モデルの一次元仮定の妥当性を, 三次元モデルにて得られる温度分布との比較により評価できる. 図 $3 b$ が, 膜厚 $L=11.5 \mu \mathrm{m}$ について上記条件を代入した三次元モデル解析結果の中心線上の温度分布と一次元モデルに よる温度分布を同じグラフ上にプロットしたものである. なお, 一次元モデルでは励起レーザー光のガウス分布・ 横方向の熱伝導の影響の 2 つが含まれておらず, 半径方向の温度分布が一定である. 図 $3 \mathrm{~b}$ より, 一次元と三次元 とで得られる結果に差はあまりないことから, 一次元モデルで現象の本質を充分に表現できると考えられる. 

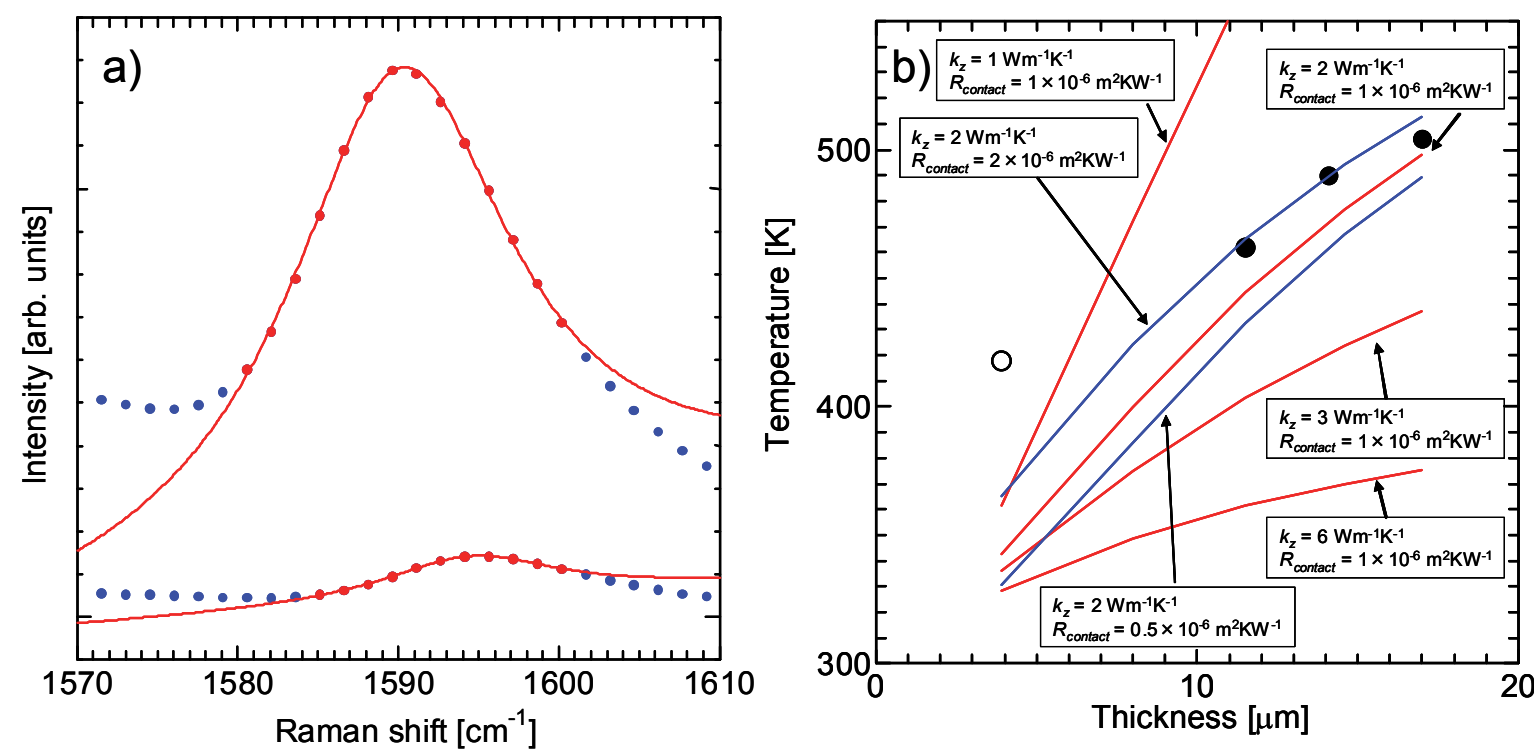

Fig. 4 a) Measured $\mathrm{G}^{+}$peak of the Raman signal. The dots are the measured signal, and the lines are the fitted lines. The signals of the peaks around $1590 \mathrm{~cm}^{-1}$ is the spectrum heated with the laser power. The smaller signal is with the low laser power, intended for measuring the referential ambient temperature peak.

b) Measured temperature results and the parameters obtaining process. The circles denote temperature measured by Raman signal. The open circle denotes the result has strong affect by the laser reflection from the substrate. The lines represent the results simulated with the indicated parameters of the vertical thermal conductivity of the film and the thermal contact resistance of the film-substrate interface. The simulated line utilized the fixed parameters of 100:1 as the vertical to lateral thermal conductivity ratio and $4 \mu \mathrm{m}$ as the spot diameter.
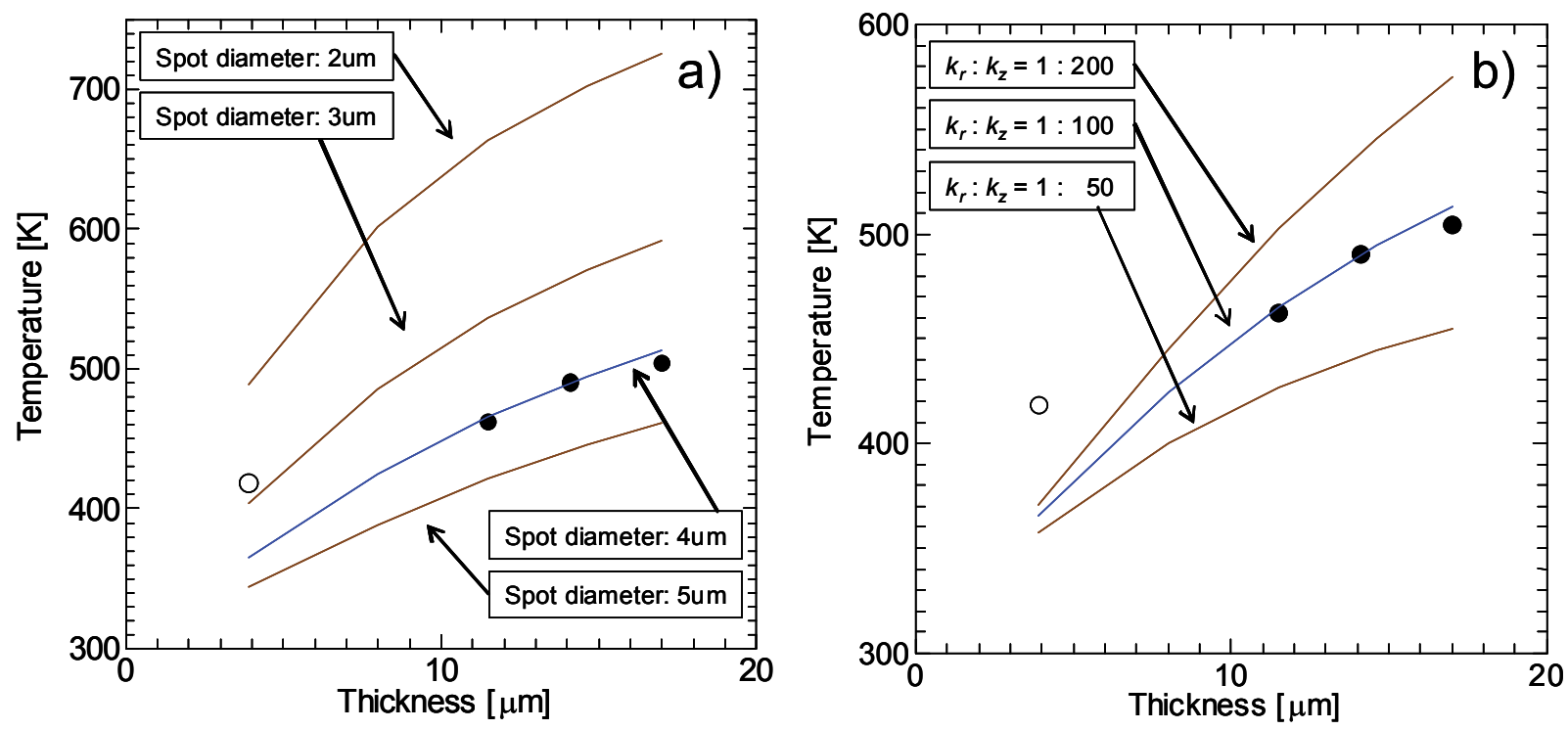

Fig. 5 a) Effect of the spot diameter. The lines represent the temperature simulated with the spot diameter as a parameter. The explanations on the circles see Fig. 4.

b) Effect of lateral to vertical thermal conductivity ratio. The lines represent the temperature computed with the lateral to vertical ratio as a parameter. The explanations on the circles see Fig. 4.

\section{4. 測定結果}

強弱二通りの励起レーザー光出力にて測定されたラマン散乱スペクトルを図 4a に示す.そして各膜厚のサンプ ルにて測定した温度をプロットしたものが図 $4 \mathrm{~b}$ のグラフ中のデータ点である.この図中に○で示した膜厚 $3.9 \mu \mathrm{m}$ のサンプルについては，励起レーザー光が VA-SWNT 膜の下面に達するまでに十分吸収されず，透過した光の基 板面での反射の影響が含まれているため, 以後の解析には用いなかった。 
ここで, 励起レーザー光のうち VA-SWNT 膜を透過して基板で反射される成分の影響の膜厚依存性について考 える. まず膜厚 $10 \mu \mathrm{m} の$ VA-SWNT 膜を仮想的に考える. 前述の吸光度 $\alpha$ を用いて計算すると, 励起レーザー光

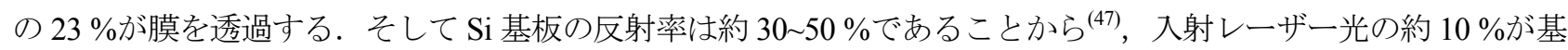
板により反射された後膜を加熱し，その結果として膜の基板近傍の温度分布を歪めることになるが，この反射光 の強度は小さいためその影響は小さい，さらに，膜の基板近傍から生ずるラマン散乱は膜を通過する過程で膜に 吸収されるため, 分光器にて検出される信号への基板近傍の温度分布の影響はさらに小さい. 以上より, 膜厚 10 $\mu \mathrm{m}$ の場合は反射光の影響は無視することが可能であると考えられる. そしてより厚い膜についても, 膜厚が大 きくなると反射光の影響はより小さくなるため, 反射の影響は無視可能である. 一方，同様の計算を膜厚 $3.9 \mu \mathrm{m}$ のサンプルに対して行うと, 入射レーザー光の $56 \%$ の光が膜を透過し, 基板から反射して再入射する強度が入射 レーザー光の 20 30\%と見積もられる. この再入射光による加熱効果は無視可能と考えられないために, 図 $4 \mathrm{~b}$ において膜厚 $3.9 \mu \mathrm{m}$ のサンプルを取り除いた.

各膜厚・縦方向熱伝導率 $k_{z}$ ・膜一基板間の接触熱抵抗 $R_{\text {contact }}$ の 3 つをパラメータとして, 先に導出した円筒座 標系の熱伝導方程式と境界条件を数值シミュレーションにより解き, 導出した代表位置での温度解からの測定値 を同じグラフにあてはめたものが図 $4 \mathrm{~b}$ である.ここで熱伝導率の縦横比を 100:1 とし, 入力レーザー光のスポッ 卜径 $2 r_{0}$ を $4 \mu \mathrm{m}$ とする. まずVA-SWNT 膜の縦方向熱伝導率 $k_{z}$ をそれぞれ $1,2,3,6 \mathrm{Wm}^{-1} \mathrm{~K}^{-1}$ としてまず熱伝導率 の最適值を求める. これにより膜の縦方向熱伝導率は $k_{z}=2 \mathrm{Wm}^{-1} \mathrm{~K}^{-1}$ と求まる. この值をもとに膜一基板間接触熱 抵抗 $R_{\text {contact }}$ を $0.5,1,2 \times 10^{-6} \mathrm{~m}^{2} \mathrm{KW}^{-1}$ と変化させて最適值を求める. その結果膜一基板間接触熱抵抗が $R_{\text {contact }}=$ $2 \times 10^{-6} \mathrm{~m}^{2} \mathrm{KW}^{-1}$ と求まる.

この結果は縦横方向の熱伝導率比の值と入力レーザー光のスポットサイズを仮定していることから一意に決ま る值ではないため,これらによる影響を検証する.検証にあたり, 縦方向熱伝導率 $k_{z}$ と膜一基板間接触熱抵抗 $R_{\text {contact }}$ は先に得られた值を用い, 各パラメータの影響を探るものとする. まず, 縦横方向の熱伝導率比の影響について は, 今回用いた熱伝導率の縦横比 100:1 を基準とし， 50:1( $\left.k_{r}=0.04 \mathrm{Wm}^{-1} \mathrm{~K}^{-1}\right), \quad 200: 1\left(k_{r}=0.01 \mathrm{Wm}^{-1} \mathrm{~K}^{-1}\right)$ に変化させ たものが図 $5 \mathrm{a}$ である. 次に, 入力レーザー光のスポット径の影響については, 今回用いた入力レーザー光のスポ ット径 $2 r_{0}$ を $4 \mu \mathrm{m}$ とした場合を基準とし，スポット径を $3 \mu \mathrm{m}$ と $5 \mu \mathrm{m}$ にしたものが図 $5 \mathrm{~b}$ である. これらの結果 より, 仮定する縦横方向の熱伝導率比及びスポットサイズの值の影響は無視できないものであり, 本報告の方法 では縦方向熱伝導率 $k_{z}$ 及び膜一基板間接触熱抵抗 $R_{\text {contact }}$ は熱伝導率比とスポットサイズを仮定せずに一意には決 まらないが，おおよその值（オーダー）を見積もることは可能であると考えられる.

\section{5. 考 察}

測定された VA-SWNT 膜の縦方向熱伝導率(約 $\left.2 \mathrm{Wm}^{-1} \mathrm{~K}^{-1}\right)$ ), SWNT の比熱(48)及び VA-SWNT 膜の密度 ${ }^{(49)}$ をい て熱拡散率に換算すると $10^{-5} \mathrm{~m}^{2} \mathrm{~s}^{-1}$ 程度となる. また, SWNT一本あたりに等価な熱伝導率は, 膜の熱伝導率を膜 に対する SWNT の占有率で割ることで計算できる. 占有率の導出法には 2 種類があり, SWNT を六角格子形状に 充填したバンドルを想定して SWNT 一本当たりが占める体積から求める方法では $3.6 \%$, SWNT を壁面厚さ $3.4 \AA$ の円筒と仮定して求める方法では $1.6 \%$ になる。 これらより一本あたりの熱伝導率を計算すると数十 $\mathrm{Wm}^{-1} \mathrm{~K}^{-1}$ 程 度となる. なお，ここで SWNT の直径は $2 \mathrm{~nm}$ と仮定した。

この值は報告されている理想的な条件での SWNT 単体のシミュレーション(1)(11)や測定 ${ }^{(21)(23)}$ と比較するとおよ そ1桁ほど小さく，この原因として次の二つが考えられる．まず第一に, VA-SWNT 膜の上端から下端までがつ ながっておらず，SWNT 同士の接触熱抵抗が膜の熱抵抗において支配的である可能性が考えられる．しかしなが ら ACCVD 法にて合成された VA-SWNT 膜の G/D 比は高く, これは欠陥の少なさを表しており, そのため合成中 に SWNT が折れて積み重なった上端から下端までが一本でつながっていない構造になる可能性は考えにくいと も述べることができる. 第二に, SWNT 単体の熱伝導率が低いという可能性も考えられる. これについては, 例 えば，分子動力学シミュレーションを用いて ${ }^{(50)} 1 \%$ の格子欠陥によって SWNT の熱伝導率が $1 / 4$ に低減される可 能性が示されている．しかしながら，ACCVD 法によって合成された VA-SWNT 膜は G/D 比が大きいことから欠 陥が比較的少ないと考えられるため, 熱伝導率を 1 桁も低減させる程度の欠陥が生成しているかは不明である. 
これらの点については, SWNT の G/D 比と実際の欠陥量との間の定量的な関係を含めて, 今後より詳細な調査が 必要である.

なお,この研究に関連するVA-SWNT 膜の熱抵抗を簡易的なモデルから導出する方法を Appendix B に付記する.

\section{6. 結 語}

ACCVD 法で合成した VA-SWNT 膜を用い，ラマン散乱レーザーの励起光を用いた方法により熱伝導率と接触 熱抵抗の測定を行った。 得られた縦方向熱伝導率はおよそ $2 \mathrm{Wm}^{-1} \mathrm{~K}^{-1}$ であり, 膜一基板間の接触熱抵抗はおよそ $2 \times 10^{-6} \mathrm{~m}^{2} \mathrm{KW}^{-1}$ である. 占有率から一本あたりの熱伝導率を換算すると数十 $\mathrm{Wm}^{-1} \mathrm{~K}^{-1}$ 程度となり, 理想的な条件で のSWNT 単体のシミュレーション (1)-(11) ・測定 ${ }^{(21)-(23)}$ と比べると 1 椼ぼ小さい.

\section{謝 辞}

本研究の一部は科学研究費補助金(\#22226006, \#22246023, \#19054003)及びGCOE プログラム「機械システム・ イノベーション国際拠点」による補助を受けた. 記して謝意を表する.

\section{Appendix A：ラマン散乱 G バンドピークの温度依存性}

ラマン散乱スペクトルのピークは温度依存性を示すことがこれまで報告されてきた. シリコンの $520 \mathrm{~cm}^{-1}$ 付近 に存在するピークの温度依存性 ${ }^{(51)}$ が一つの例として挙げられるあげられる. 一方, SWNT のラマン散乱スペクト ルに見られる $1594 \mathrm{~cm}^{-1}$ 付近のピークは $\mathrm{G}$ バンドと呼ばれるが，この $\mathrm{G}$ バンドピークの波数と温度との間には以 下の関係がある ${ }^{(52)}$.

$$
\omega_{\text {center }}(T)=\omega_{0}-A /\left(\exp \left(B \hbar \omega_{0} / k_{B} T\right)-1\right)
$$

ここで, $\omega$ は波数, $A \cdot B \cdot \omega_{0}$ は定数, $\hbar$ はプランク定数, $k_{B}$ はボルツマン定数, $T$ は温度である. また, $\mathrm{G}$ バン ドピークが以下の式に分解される(53).

$$
\operatorname{Ln}(\omega, \mathrm{T})=\frac{\text { Mag. }}{1+\left(\frac{\omega-\omega_{\text {center }}}{F W H M / 2}\right)^{2}}
$$

ここで, Ln はローレンツ関数, $\omega$ は波数, $\omega_{\text {center }}$ はある温度での中心波数, Mag.は信号強度, FWHM はローレン ツ関数の半值幅である. なお，信号強度及び半值幅は以下の温度依存性を示す ${ }^{(53)}$.

$$
\text { Mag. }=\exp (-\mathrm{T} / 430)
$$

$\mathrm{FWHM}=8.54+\mathrm{T} \times 1.40 \times 10^{-2}$

ラマン散乱スペクトルの温度依存性を利用して各種材料の熱伝導率を求める研究はこれまでにも行われてきた. ラマン分光の励起レーザー光を熱源として熱伝導率を測定した報告としては, メソポーラスシリコン層の測定 ${ }^{(54)}$ がある.これに用いられた方法を拡張し, サブミクロンの厚みを持つ膜の熱伝導率が測定されている(55). シリコ ンのラマン散乱スペクトルのローレンツ関数にみられる温度依存性を用いてシリコン薄膜の熱伝導率が測定され ている( ${ }^{(5)}$. 一方，ラマン分光を用いた炭素材料の熱伝導特性の測定としては，カーボンナノチューブとグラフェ ンについてこれまで報告されている. カーボンナノチューブについては, SWNT バンドルをラマン励起光により 側面から加熱してラマン信号より温度を測定することで熱伝導特性が求められており ${ }^{(19)(20)}$, 電気加熱した MWNT の温度をラマン分光により測定し熱伝導率が求められている ${ }^{(57)}$. グラフェンについては, 励起光により加熱した 
グラフェンのラマン散乱スペクトルより温度を測定する方法で熱伝導特性の測定が行われており (58), 空孔上に架 橋したグラフェンを励起レーザー光にて加熱し測定されている ${ }^{(59)}$. また，グラフェンについては，上記の $\mathrm{G}$ バ ンドピークの温度依存性ではなくストークスラマン一アンチストークスラマン強度比の温度依存性を利用した熱 伝導率の測定もある(60).

\section{Appendix B: 簡易モデルによる熱抵抗の導出}

この付録においては，励起レーザ一光の加熱効果によりVA-SWNT 膜の熱抵抗を簡易的なモデルから導出する 方法を述べる. まず，励起レーザー光がスポットに均一に入射するとし，上端でレーザー光が吸収されるとする とし，VA-SWNT 膜横方向の熱伝導率が縦方向と比べて十分小さいとモデル化する．これを簡易モデルと定義す る.このモデルの下では, 変換された熱は横方向に伝導せずVA-SWNT 膜を通じ Si 基板に達する. このモデルを 図示したものが図 B1a であり, 数式を交えると次のように表現される. $2 r_{0}$ をスポット径とし, 顕微鏡により強度 $P$ のレーザー光がスポット $A=\pi r_{0}{ }^{2}$ に入射すると焦点において熱流束は $q "=P / A$ であり, 熱抵抗・熱流束・測定 される温度の 3 つには次の関係がある.

$$
q^{\prime \prime}=\left(1 /\left(R_{\text {partofCNT }}+R_{\text {contact }}\right)\right) \Delta T
$$

ここで， $R_{\text {partofCNT }}$ はVA-SWNT 膜の熱抵抗のうち励起レーザ一光が十分に吸光された領域の熱抵抗であり， $R_{\text {contact }}$ は膜一基板界面の接触熱抵抗であり， $\Delta T$ は測定される温度值と常温との温度差である. 入力レーザー光パワー $P$ は $0.7 \mathrm{~mW}$ であり，入力レーザー光のスポット径 $2 r_{0}$ を $4 \mu \mathrm{m}$ と仮定した時，このモデルにより得られる熱抵抗は $R_{\text {total }}=2 \sim 4 \times 10^{-6} \mathrm{~m}^{2} \mathrm{KW}^{-1}$ である. 膜内での励起レーザ一光の強度分布から生じる影響が強く出るため，このモデル により得られる熱抵抗值は実際の值と比べて若干低めとなり，また膜厚が薄い場合はよりずれが大きくなるが， この法は各サンプルを簡便に評価する方法として有用と考えられる.

この簡易モデルの有効性は 1 次元モデルとの比較により評価できる. 簡易モデルにおいて内部温度分布は次の 式にて表わされる.

$$
T(z)=\frac{P}{k_{z} A}(-(z-L))+\frac{P}{A} R_{\text {contact }}+T_{\text {sub }}
$$

この式及び一次元温度分布の式を膜厚 $10 \mu \mathrm{m}$ についてグラフとしたものが図 B1bである. このグラフより，同じ 条件を代入した場合に簡易モデルは若干高い温度を示すことが見てとれる。これはすなわち，測定された温度を 簡易モデルにあてはめた場合に得られる熱抵抗值は実際の值より若干高めとなることを示している。これらのこ
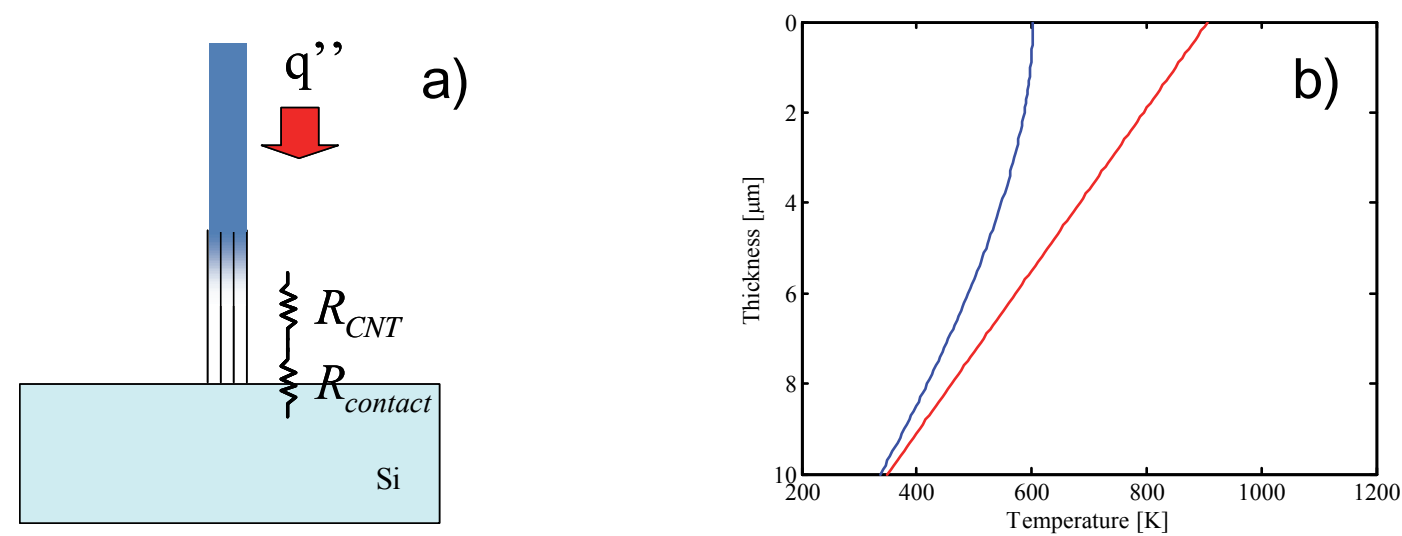

Fig. B1 a) Schematic illustration of the simplified model. Since the lateral heat conduction is neglected, the absorbed heat directly passes through the film thermal resistance and the interfacial contact resistance to the Si substrate.

b) Comparison graph of the one-dimensional solution and the simplified model. The blue line denotes the temperature distribution of the one-dimensional equation, and the red line indicates the temperature profile of the simplified model. The thickness employed for the simulation was $10 \mu \mathrm{m}$. 
とから，膜に対して吸光度のより高い波長にて測定しレーザー光を膜の上面にて大部分吸収させることでモデル により得られる熱抵抗值と実際の值とのずれを低減し精密な測定をするという今後の方向性が考えられる.

\section{文献}

(1) Berber, S., Kwon, Y., and Tománek, D., "Unusually high thermal conductivity of carbon nanotubes", Physical Review Letters, Vol. 84, No. 2 (2000), pp. 4613-4616.

(2) Osman, M.A. and Srivastava, D., "Temperature dependence of the thermal conductivity of single-wall carbon nanotubes", Nanotechnology, Vol. 12 (2001), pp. 21-24.

(3) Che, J., Çağin, T., and Goddard III, W.A., "Thermal conductivity of carbon nanotubes”, Nanotechnology, Vol. 11 (2000), pp. 65-69.

(4) Moreland, J.F., Freund, J.B., and Chen, G., "The disparate thermal conductivity of carbon nanotubes and diamond nanowires studied by atomistic simulation", Microscale Thermophysical Engineering, Vol. 8 (2004), pp. 61-69.

(5) Maruyama, S., "A molecular dynamics simulation of heat conduction in finite length SWNTs", Physica B, Vol. 323 (2002), pp. 193-195.

(6) Maruyama, S., "A molecular dynamics simulation of heat conduction of a finite length single-walled carbon nanotube", Microscale Thermophysical Engineering, Vol. 7 (2003), pp. 41-50.

(7) Mingo, N. and Broido, D.A., "Carbon nanotube ballistic thermal conductance and its limits", Physical Review Letters, Vol. 95 (2005), pp. 096105-1-4.

(8) Mingo, N. and Broido, D.A., "Length dependence of carbon nanotube thermal conductivity and the "Problem of Long Waves"', Nano Letters, Vol. 5, No. 7 (2005), pp. 1221-1225.

(9) Maruyama, S., Igarashi, Y., Taniguchi, Y., and Shiomi, J., "Anisotropic heat transfer of single-walled carbon nanotubes", Journal of Thermal Science and Technology, Vol. 1, No. 2 (2006), pp. 138-148.

(10) Shiomi, J. and Maruyama, S., "Molecular dynamics of diffusive-ballistic heat conduction in single-walled carbon nanotubes", Japanese Journal of Applied Physics, Vol. 47, No.4 (2008), pp. 2005-2009.

(11) Yamamoto, T., Konabe, S., Shiomi, J., and Maruyama, S., "Crossover from ballistic to diffusive thermal transport in carbon nanotubes”, Applied Physics Express, Vol. 2, No. 9 (2009), pp. 095003-1-3.

(12) Yi, W., Lu, L., Dian-Lin, Z., Pan, Z.W., and Xie, S.S., "Linear specific heat of carbon nanotubes", Physical Review B, Vol. 59, No. 14 (1999), pp. R9015-9018.

(13) Kim, P., Shi, L., Majumdar, A., and McEuen, P.L., "Thermal Transport Measurements of Individual Multiwalled Nanotubes", Physical Review Letters, Vol. 87, No. 21 (2001), pp. 215502-1-4.

(14) Fujii, M., Zhang, X., Xie, H., Ago, H., Takahashi, K., Ikuta, T., Abe, H., and Shimizu, T., "Measuring the Thermal Conductivity of a Single Carbon Nanotube", Physical Review Letters, Vol. 95 (2005), pp. 065502-1-4.

(15) Choi, T.-Y., Poulikakos, D., Tharian, J., and Sennhauser, U., "Measurement of thermal conductivity of individual multiwalled carbon nanotubes by the 3- $\omega$ method", Applied Physics Letters, Vol. 87 (2005), pp. 013108-1-3.

(16) Choi, T.Y., Poulikakos, D., Tharian, J., and Sennhauser, U., "Measurement of thermal conductivity of individual multiwalled carbon nanotubes by the four-point three- $\omega$ method", Nano Letters, Vol. 6, No. 8 (2006), pp. 1589-1593.

(17) Shi, L., Li, D., Yu, C., Jang, W., Yao, Z., Kim, P., and Majumdar, A., "Measuring Thermal and Thermoelectric Properties of One-Dimensional Nanostructures Using a Microfabricated Device", Journal of Heat Transfer, Vol. 125 (2003), pp. 881-888.

(18) Hou, J., Wang, X., Vellelacheruvu, P., Guo, J., Liu, C., Cheng, H.-M., "Thermal characterization of single-wall carbon nanotube bundles using the self-heating $3 \omega$ technique", Journal of Applied Physics, Vol. 100 (2006), pp. 124314-1-9.

(19) Hsu, I.-K., Kumar, R., Bushmaker, A., Cronin, S.B., Pettes, M.T., Shi, L., Brintlinger, T., Fuhrer, M.S., and Cumings, J., "Optical measurement of thermal transport in suspended carbon nanotubes", Applied Physics Letters, Vol. 92 (2008), pp. 063119-1-3.

(20) Hsu, I.-K., Pettes, M.T., Bushmaker, A., Aykol, M., Shi, L., and Cronin, S.B., "Optical absorption and thermal transport of individual suspended carbon nanotube bundles", Nano Letters, Vol. 9, No. 2 (2009), pp. 590-594. 
(21) Yu, C., Shi, L., Yao, Z., Li, D., and Majumdar, A., "Thermal conductance and thermopower of an individual single-wall carbon nanotube", Nano Letters, Vol. 5, No. 9 (2005), pp. 1842-1846.

(22) Pop, E., Mann, D., Wang, Q., Goodson, K., and Dai, H., “Thermal conductance of an individual single-wall carbon nanotube above room temperature", Nano Letters, Vol. 6, No. 1 (2006), pp. 96-100.

(23) Wang, Z.L., Tang, D.W., Li, X.B., Zheng, X.H., Zhang, W.G., Zheng, L.X., Zhu, Y.T., Jin, A.Z., Yang, H.F., and Gu, C.Z., "Length-dependent thermal conductivity of an individual SWCNT", Applied Physics Letters, Vol. 91 (2007), pp. 123119-1-3.

(24) Duong, H.M., Einarsson, E., Okawa, J., Xiang, R., and Maruyama, S., "Thermal degradation of single-walled carbon nanotubes", Japanese Journal of Applied Physics, Vol. 47, No. 4 (2008), pp. 1994-1999.

(25) Yang, D.J., Zhang, Q., Chen, G., Yoon, S.F., Ahn, J., Wang, S.G., Zhou, Q., Wang, Q., and Li, J.Q., “Thermal conductivity of multiwalled carbon nanotubes“, Physical Review B, Vol. 66 (2002), pp. 165440-1-6.

(26) Wang, X., Zhong, Z., and Xu, J., "Noncontact thermal characterization of multiwall carbon nanotubes", Journal of Applied Physics, Vol. 97 (2005), pp. 064302-1-5.

(27) Borca-Tasciuc, T., Vafaei, S., Borca-Tasciuc, D.-A., Wei, B.Q., Vajtai, R., and Ajayan, P.M., “Anisotropic thermal diffusivity of aligned multiwall carbon nanotube arrays", Journal of Applied Physics, Vol. 98 (2005), pp. 054309-1-6.

(28) Hu, X.J., Padilla, A.A., Xu, J., Fisher, T.S., and Goodson, K.E., “3-Omega Measurements of Vertically Oriented Carbon Nanotubes on Silicon", Journal of Heat Transfer, Vol. 128 (2006), pp. 1109-1113.

(29) Tong, T., Zhao, Y., Delzeit, L., Kashani, A., Meyyappan, M., and Majumdar, A., "Dense vertically aligned multiwalled carbon nanotube arrays as thermal interface materials“, IEEE Transactions on Components and Packaging Technologies, Vol. 30, No. 1 (2007), pp. 92-100.

(30) Cola, B.A., Xu, J., Cheng, C., Xu, X., Fisher, T.S., and Hu, H., "Photoacoustic characterization of carbon nanotube array thermal interfaces", Journal of Applied Physics, Vol. 101 (2007), pp. 054313-1-9.

(31) Shaikh, S., Li, L., Lafdi, K., Huie, J., “Thermal conductivity of an aligned carbon nanotube array”, Carbon, Vol. 45 (2007), pp. 2608-2643.

(32) Son, Y., Pal, S.K., Borca-Tasciuc, T., Ajayan, P.M., and Siegel, R.W., "Thermal resistance of the native interface between vertically aligned multiwalled carbon nanotube arrays and their SiO2/Si substrate", Journal of Applied Physics, Vol. 103 (2008), pp. 024911-1-7.

(33) Pal, S.K., Son, Y., Borca-Tasciuc, T., Borca-Tasciuc, D.-A., Kar, S., Vajtai, R., and Ajayan, P.M., "Thermal and electrical transport along MWCNT arrays grown on Inconel substrates”, Journal of Materials Research, Vol. 23, No. 8 (2008), pp. 2099-2105.

(34) Xie, H., Cai, A., and Wang, X., "Thermal diffusivity and conductivity of multiwalled carbon nanotube arrays", Physics Letters A, Vol. 369 (2007), pp. 120-123.

(35) Xu, J., and Fisher, T.S., "Enhancement of thermal interface materials with carbon nanotube arrays", International Journal of Heat and Mass Transfer, Vol. 49 (2006), pp. 1658-1666.

(36) Hata, K., Futaba, D.N., Mizuno, K., Namai, T., Yumura, M., and Iijima, S., "Water-assited highly efficient synthesis of impurity-free single-walled carbon nanotubes", Science, Vol. 306 (2004), pp. 1362-1364.

(37) Akoshima, M., Hata, K., Futaba, D.N., Mizuno, K., Baba, T., and Yumura, M., "Thermal diffusivity of single-walled carbon nanotube forest measured by laser flash method", Japanese Journal of Applied Physics, Vol. 48 (2009), pp. 05EC07-1-6.

(38) Zhang, G., Mann, D., Zhang, L., Javey, A., Li, Y., Yenimelez, E., Wang, Q., McVittie, J.P., Nishi, Y., Gibbons, J., and Dai, H., "Ultra-high-yield growth of vertical single-walled carbon nanotubes: Hidden roles of hydrogen and oxygen", Proceedings of the National Academy of Science, Vol. 102, No. 45 (2005), pp. 16141-16145.

(39) Panzer, M.A., Zhang, G., Mann, D., Hu, X., Pop, E., Dai, H., and Goodson, K.E., "Thermal properties of metal-coated vertically aligned single-wall nanotube arrays", Journal of Heat Transfer, Vol. 130 (2008), pp. 052401-1-9.

(40) Murakami, Y., Chiashi, S., Miyauchi, Y., Hu, M., Ogura, M., Okubo, T., and Maruyama, S., "Growth of vertically aligned single-walled carbon nanotube films on quartz substrates and their optical anisotropy”, Chemical Physics Letters, Vol. 385 (2004), pp. 298-303. 
(41) Panzer, M. A., Duong, H. M., Okawa, J., Shiomi, J., Wardle, B.L., Maruyama, S., and Goodson, K. E., "Temperature-dependent phonon conduction and nanotube engagement in metalized single wall carbon nanotube films", Nano Letters, Vol. 10 (2010), pp. 2395-2400.

(42) Mizuno, K., Ishii, J., Kishida, H., Hayamizu, Y., Yasuda, S., Futaba, D.N., Yumura, M., and Hata, K., “A black body absorber from vertically aligned single-walled carbon nanotubes", Proceedings of the National Academy of Sciences, Vol. 106, No. 15 (2009), pp. 6044-6047.

(43) Yovanovich, M.M., Culham, J.R., and Teertstra, P., "Analytical modeling of spreading resistance in flux tubes, half spaces, and compound disks", IEEE Transactions on Components and Packaging Technologies Part A, Vol. 21, No. 1 (1998), pp. 168-176. The applied condition is same as the 'Isoflux contact on layer on half-space' with the $\mathrm{k} 2=\mathrm{k} 1$ stated in this paper. See also URL http://mhtlab.uwaterloo.ca/intro_disk.html.

(44) Lide, D.R., ed., CRC Handbook of Chemistry and Physics, 72nd ed. (1991-1992), Chap. 4, p. 148, CRC Press.

(45) Einarsson, E., Murakami, Y., Kadowaki, M., and Maruyama, S., "Growth dynamics of vertically aligned single-walled carbon nanotubes from in situ measurements", Carbon, Vol. 46 (2008), pp. 923-930.

(46) Lin, C.-T., Lee, C.-Y., Chin, T.-S., Ishikawa, K., Xiang, R., Shiomi, J., and Maruyama, S., "Anisotropic electrical conduction of vertically-aligned single-walled carbon nanotube films", Carbon, Vol. 49 (2011), pp. 1446-1452.

(47) Pauly, H., "Effects of different polishing methods on the reflectance of silicon", TMPM Tschermaks Mineralogische und Petrographische Mittteilungen, Vol. 35 (1986), pp. 261-273.

(48) Hone, J., Batlogg, B., Benes, Z., Johnson, A.T., and Fischer, J.E., "Quantized phonon spectrum of single-wall carbon nanotubes", Science, Vol. 289 (2000) pp. 1730-1733.

(49) Xiang, R., Yang, Z., Zhang, Q., Luo, G., Qian, W., Wei, F., Kadowaki, M., Einarsson, E., and Maruyama, S., "Growth deceleration of vertically aligned carbon nanotube arrays: catalyst deactivation or feedstock diffusion controlled?", Journal of Physical Chemistry C, Vol. 112 (2008), pp. 4892-4896.

(50) Kondo, N., Yamamoto, T., and Watanabe, K., "Molecular-dynamics simulations of thermal transport in carbon nanotubes with structural defects", e-Journal of Surface Science and Nanotechnology, Vol. 4 (2006), pp. 239-243.

(51) Balkanski, M., Wallis, R.F., and Haro, E., “Anharmonic effects in light scattering due to optical phonons in silicon”, Physical Review B, Vol. 28, No. 4 (1983), pp. 1928-1934.

(52) Chiashi, S., Murakami, Y., Miyauchi, Y., and Maruyama, S., “Temperature dependence of Raman scattering from single-walled carbon nanotubes: Undefined radial breathing mode peaks at high temperatures", Japanese Journal of Applied Physics, Vol. 47, No. 4 (2008), pp. 2010-2015.

(53) 千足昇平, 東京大学博士論文, (2005), http://www.photon.t.u-tokyo.ac.jp/thesis/index-j.html (参照日 2011 年 11 月 14 日).

(54) Périchon, S., Lysenko, V., Roussel, Ph., Remaki, B., Champagnon, B., Barbier, D., and Pinard, P., "Technology and micro-Raman characterization of thick meso-porous silicon layers for thermal effect microsystems", Sensors and Actuators, Vol. 85 (2000), pp. 335-339.

(55) Huang, S., Ruan, X., Zou, J., Fu, X., and Yang, H., “Thermal conductivity measurement of submicrometer-scale silicon dioxide films by an extended micro-Raman method", Microsystem Technologies, Vol. 15 (2009), pp. 837-842.

(56) Liu, X., Wu, X., and Ren, T., "In situ and noncontact measurement of silicon membrane thermal conductivity", Applied Physics Letters, Vol. 98 (2011), pp. 174104-1-3.

(57) Li, Q., Liu, C., Wang, X., and Huang, S., "Measuring the thermal conductivity of individual carbon nanotubes by the Raman shift method", Nanotechnology, Vol. 20 (2009), pp. 145702-1-5.

(58) Balandin, A.A., Ghosh, S., Bao, W., Calizo, I., Teweldebrhan, D., Miao, F., and Lau, C.N.,'Superior thermal conductivity of single-layer graphene", Nano Letters, Vol. 8, No. 3 (2008), pp. 902-907.

(59) Cai, W., Moore, A.L., Zhu, Y. , Li, X., Chen, S., Shi, L., and Ruoff, R.S., "Thermal transport in suspended and supported monolayer graphene grown by chemical vapor deposition", Nano Letters, Vol. 10, No. 5 (2010), pp. 1645-1651.

(60) Faugeras, C., Faugeras, B., Orlita, M., Potemski, M., Nair, R.R., and Geim, A.K., "Thermal conductivity of graphene in corbino membrane geometry", ACS Nano, Vol. 4, No. 4 (2010), pp. 1889-1892. 